\title{
Etiology of Hypospadias: A Comparative Review of Genetic Factors and Developmental Processes Between Human and Animal Models
}

This article was published in the following Dove Press journal: Research and Reports in Urology

\author{
Jun Chang $\mathbb{D}^{1,2}$ \\ Shanshan Wang' \\ Zhengui Zheng' \\ 'Department of Physiology, School of \\ Medicine, Southern Illinois University \\ Carbondale, Carbondale, IL 6290I, USA; \\ ${ }^{2}$ School of Life Science, Jiangxi Science \& \\ Technology Normal University, \\ Nanchang, Jiangxi 3300I3, People's \\ Republic of China
}

\begin{abstract}
Hypospadias is a congenital anomaly of the penis with an occurrence of approximately 1 in 200 boys, but the etiology of the majority of hypospadias has remained unknown. Numerous genes have been reported as having variants in hypospadias patients, and many studies on genetic deletion of key genes in mouse genital development have also been published. Until now, no comparative analysis in the genes related literature has been reported. The basic knowledge of penile development and hypospadias is mainly obtained from animal model studies. Understanding of the differences and similarities between human and animal models is crucial for studies of hypospadias. In this review, mutations and polymorphisms of hypospadias-related genes have been compared between humans and mice, and differential genotype-phenotype relationships of certain genes between humans and mice have been discussed using the data available in PubMed and MGI online databases, and our analysis only revealed mutations in seven out of 43 human hypospadias related genes which have been reported to show similar phenotypes in mutant mice. The differences and similarities in the processes of penile development and hypospadias malformation among human and commonly used animal models suggest that the guinea pig may be a good model to study the mechanism of human penile development and etiology of hypospadias.
\end{abstract}

Keywords: hypospadias, genetic factors, external genital development, animal models

\section{Introduction and Review Objectives}

Hypospadias is one of the most common congenital penile malformations, with an occurrence of approximately 1 in 200 male newborns. ${ }^{1}$ Patients with hypospadias confront serious psychological problems and physical difficulties with urination and sexual functions. Generally, hypospadias represents a disruption of normal penile development between 8 and 14 weeks of gestation, resulting in the abnormal urethral opening on the ventral surface of the penis. ${ }^{2}$ Based on the severity, hypospadias can be divided into three degrees: mildest anterior forms, with the urethral opening on the glandular or subcoronal position of penis, more severe middle hypospadias, in which the meatus opens on the midshaft of the penis, and the most severe posterior forms containing penoscrotal, scrotal, and perineal openings. ${ }^{3}$

Unfortunately, the etiology of hypospadias in the majority patients has remained unknown. Genetic and environmental factors are the main susceptibilities. Although androgen is known to be essential for the sexual differentiation and penile development, only a small percentage of severe hypospadias can be explained by the genetic syndromes or defects involving the androgen receptor $(A R)$ gene. ${ }^{4}$ Interactions between genes and 
environmental factors, including placental insufficiency, exogenous endocrine-disrupting chemicals, such as vinclozolin ${ }^{5}$ and di-n-butyl phthalate, ${ }^{6}$ acting on polymorphic genes or inducing epigenetic changes, may greatly contribute to hypospadias development. The mechanism of external genital development, and genetic and environmental factors underlying hypospadias and animal models had been intensively reviewed by different research groups. ${ }^{7-11}$

Our knowledge about penile development and hypospadias is mainly based on the studies in animal models. Mice $^{12}$ and rats ${ }^{13}$ are the most commonly used laboratory animals for hypospadias modeling, in addition, other animals such as guinea pigs, ${ }^{14}$ rabbits, ${ }^{15}$ and $\operatorname{dog} s^{16}$ have also been used in hypospadias research. Unfortunately, differences exist between human and animal models in the mechanisms of normal penile development and hypospadias malformation. Without considering the differences, results derived from animal models of hypospadias are less reliable. Therefore, understanding the differences and similarities between human and animal models is crucial to the mechanism study of hypospadias. This paper reviews the etiology of hypospadias, including the influences of genetic, epigenetic factors, as well as animal models and their differences and similarities compared with humans.

\section{Literature Search and Data Synthesis}

We conducted a literature search using PubMed for all publications before September 1, 2020 for hypospadias related genes with key words "hypospadias and gene", "hypospadias and polymorphism", "hypospadias and mouse", and "mouse external genitalia and genes", we also use "hypospadias" and several domestic animals to find out the other animal models, such as "rabbit", "dog", and "horse", of hypospadias. We included systematic reviews of all literature and revealed reported hypospadias related genes identified from humans and mice. Phenotypic data of mouse mutants were acquired through both the literature searching using PubMed and checking the Mouse Genome Informatics online database resource (http://www.informatics.jax.org/).

\section{Genetic and Epigenetic Factors of Hypospadias}

Genetic inheritance has long been inferred to be one of the causes of hypospadias. ${ }^{17}$ Hypospadias was found to have a strong familial component and also to aggregate within more distant relatives. One large sample cohort study found $0.45 \%$ of boys had hypospadias; among these patients, $4.2 \%$ had at least one family member with a history of hypospadias, and the inheritance of hypospadias was transmitted equally through the paternal and maternal sides. ${ }^{18}$ Hypospadias fathers were deemed to have high potential to have hypospadias sons, the incidence of hypospadias for those whose fathers were affected by hypospadias was $27 \%$ as reported. ${ }^{19}$ And first degree relatives of hypospadias infants had more malformations other than hypospadias than controls. ${ }^{20}$ In recent years, a lot of gene polymorphisms/mutations and some epigenetic marks have been revealed in hypospadias patients, with more and more studies suggesting multifactorial inheritance for the majority cases of hypospadias.

Current epidemiology and laboratory studies have suggested that epigenetic alterations may contribute to abnormal male sexual differentiation including hypospadias. Higher methylation level of $A R$ gene in the foreskin, resulting in a decreased expression of the AR protein, might be involved in the pathogenesis of hypospadias. ${ }^{21}$ Ohsako et $\mathrm{al}^{22}$ reported a negative association of methylation level of the SRD5A2 gene with the mRNA expression levels of CYP1 family genes in the preputial tissue of patients with hypospadias and suggested it is likely to indicate the involvement of chemical exposure and epigenetic change in the onset of hypospadias. Significant associations were observed between methylation levels of individual $\mathrm{CpG}$ sites and hypospadias, and DNA methylation patterns have been used in identifying and evaluating new candidate genes that may be involved in the etiology of hypospadias. ${ }^{23}$ Nevertheless, data about the effect of methylation of genes on the development of hypospadias are limited, and the relation between other epigenetic factors involved in DNA or histone modifications with hypospadias is mostly unknown.

\section{Mutations and Polymorphisms in Hypospadias Patients and Mice}

Polymorphism in biology refers to the occurrence of two or more genetically phenotypes in a certain population. The polymorphisms of certain genes have been reported to cause hypospadias in humans, the comparison of key gene mutations and polymorphisms associated with hypospadias, and the relevant phenotypes between humans and mice are summarized in Table 1. 
Table I Gene Variants and Relevant Phenotypes in Hypospadias Patients and Mice

\begin{tabular}{|c|c|c|c|c|}
\hline $\begin{array}{l}\text { Gene } \\
\text { Name }\end{array}$ & $\begin{array}{l}\text { Phenotype of EG (or Urogenital System) } \\
\text { in Knockout Male Mice }\end{array}$ & $\begin{array}{l}\text { Gene Variants in Hypospadias } \\
\text { Patients }\end{array}$ & $\begin{array}{l}\text { Clinical Hypospadias } \\
\text { Type }\end{array}$ & Reference \\
\hline $\begin{array}{l}\text { AKRIC3 } \\
(\text { HSDI7B5) }\end{array}$ & Not available & c. $643 \mathrm{G}>\mathrm{A}$ & Penile & [5I] \\
\hline \multirow[t]{7}{*}{$A R^{\wedge}$} & \multirow{7}{*}{$\begin{array}{l}\text { Phenotypes vary from female-like EG, } \\
\text { ambiguous genitalia to hypospadias, } \\
\text { micropenis }^{24,25}\end{array}$} & Methylation & Glandular & [2I] \\
\hline & & c. $2519 \mathrm{G}>\mathrm{A}$, c. $2564 \mathrm{G}>\mathrm{A}$ & Perineal & \multirow[t]{3}{*}{ [27] } \\
\hline & & c. $2525 T>C$ & Scrotal & \\
\hline & & c. $1991 \mathrm{C}>\mathrm{T}$ & Glandular & \\
\hline & & c. $2577 \mathrm{C}>\mathrm{A}$ & Penile & \\
\hline & & CAG repeat & $\begin{array}{l}\text { Variable in different } \\
\text { races }\end{array}$ & [28] \\
\hline & & GGN repeat & Penile & [30] \\
\hline & & c. $1789 \mathrm{G}>\mathrm{A}$ & Perineal & [46] \\
\hline ATF3 $^{\wedge}$ & No obvious phenotype ${ }^{100}$ & rsIIII9982, rs3125289, rsI877474 & Hypospadias & {$[101]$} \\
\hline $\mathrm{BNC2}^{\mathbf{4}}$ & Distal hypospadias in newborn mice ${ }^{102}$ & $\begin{array}{l}\text { c. } 916 C>G, \text { c. } 1735 C>T, \text { c. } 719 A>G, \\
\text { c. } 847 A>G, \text { c. } 2768 C>T, \text { c. } 1240 C>G \text {, } \\
\text { c. } 455 A>G\end{array}$ & Distal & [102] \\
\hline $\mathrm{BMP4} 4$ & Hypoplasia of genital tubercle ${ }^{77}$ & c. $619 \mathrm{C}>\mathrm{G}, \mathrm{c} .668 \mathrm{G}>\mathrm{A}, \mathrm{c} .75 \mathrm{IC}>\mathrm{T}$ & Penoscrotal and penile & [80] \\
\hline \multirow[t]{3}{*}{$\mathrm{BMP7}^{\mathbf{\Lambda}}$} & \multirow{3}{*}{$\begin{array}{l}\text { Arrest in cloacal septation, and severe defects } \\
\text { in genital urethra and mesenchyme }{ }^{78}\end{array}$} & rs6070007 & Moderate & \multirow[t]{2}{*}[74]{} \\
\hline & & $\begin{array}{l}\text { rs6127980 } \\
\text { rs6127978, rs6127985 }\end{array}$ & $\begin{array}{l}\text { Severe and mild } \\
\text { Severe }\end{array}$ & \\
\hline & & c. $907 \mathrm{C}>\mathrm{T}$ & Glandular & [80] \\
\hline $\mathrm{CDHII}$ & No obvious phenotype $\mathrm{I}^{1 / 4}$ & Loss of function mutation & $\begin{array}{l}\text { Elsahy-Waters } \\
\text { syndrome with } \\
\text { hypospadias }\end{array}$ & [103] \\
\hline CTNNBI & Hypoplasia or hypospadias ${ }^{79}$ & $347 \mathrm{TCT} \rightarrow \mathrm{CCT}$, Ser $45 \rightarrow$ Pro & Hypospadias & {$[8 I]$} \\
\hline CYPIIAI & Female $\mathrm{EG}^{47}$ & c. $666 \mathrm{~T}>\mathrm{C}$ & Mid-shaft & {$[48]$} \\
\hline \multirow[t]{2}{*}{ DGKK } & Not available & rs1934179, rs7063116 & Anterior or middle & {$[105]$} \\
\hline & & rsI1091748, rs12171755 & Anterior or middle & [104] \\
\hline $\mathrm{EMX} 2^{\Delta}$ & $\begin{array}{l}\text { Degeneration of the Wolffian duct and } \\
\text { mesonephric tubules }{ }^{97}\end{array}$ & 10q25.3-q26.12 microdeletion & $\begin{array}{l}\text { Ranging from } \\
\text { hypospadias to } \\
\text { complete sex reversal }\end{array}$ & [98] \\
\hline $\begin{array}{l}\text { EPHRIN-B2 } \\
\text { and } \\
\text { EPHB2 }^{\Delta}\end{array}$ & Hypospadias and anorectal malformations ${ }^{84}$ & & Not available & \\
\hline $\mathrm{ESRI}^{\wedge}$ & No obvious phenotype ${ }^{33}$ & $\begin{array}{l}\text { Pvull and Xbal C-A haplotype } \\
\text { (rs2234693, rs9340799) }\end{array}$ & Mild & [34] \\
\hline
\end{tabular}


Table I (Continued).

\begin{tabular}{|c|c|c|c|c|}
\hline $\begin{array}{l}\text { Gene } \\
\text { Name }\end{array}$ & $\begin{array}{l}\text { Phenotype of EG (or Urogenital System) } \\
\text { in Knockout Male Mice }\end{array}$ & $\begin{array}{l}\text { Gene Variants in Hypospadias } \\
\text { Patients }\end{array}$ & $\begin{array}{l}\text { Clinical Hypospadias } \\
\text { Type }\end{array}$ & Reference \\
\hline & & $\begin{array}{l}\text { AGATA haplotype (SNPs I0-I4: } \\
\text { rs926779, rs3020364, rs6932902, } \\
\text { rs302037I, rs3020375) }\end{array}$ & Hypospadias & [35] \\
\hline $\mathrm{ESR} 2 \boldsymbol{\Lambda}$ & No obvious phenotype $\mathrm{e}^{33}$ & rs944050, rs3832949 & Hypospadias & [37] \\
\hline FGF8 ${ }^{\wedge}$ & No obvious phenotype ${ }^{75}$ & $\begin{array}{l}\mathrm{c} .590 \mathrm{C}>\mathrm{G}, \mathrm{c} .582-62 \mathrm{G}>\mathrm{A} \\
(\mathrm{rs} 3218238)\end{array}$ & Hypospadias & [73] \\
\hline \multirow[t]{2}{*}{ FGFR2 } & \multirow[t]{2}{*}{ Hypospadias ${ }^{69}$} & $\begin{array}{l}\mathrm{c} .550+27 \mathrm{C}>\mathrm{T}, \mathrm{c} .727+180 \mathrm{~T}>\mathrm{G}, \mathrm{c} .382 \\
+52 \rightarrow \mathrm{G}, \mathrm{c} .2454 \mathrm{C}>\mathrm{T}\end{array}$ & Hypospadias & \multirow[t]{2}{*}[73]{} \\
\hline & & c.830T>C (rs755793) & Mid-penile & \\
\hline \multirow[t]{3}{*}{ FGFIO ${ }^{\Delta}$} & \multirow[t]{3}{*}{ Hypospadias $^{68}$} & rs| 482679 & Severe & \multirow[t]{3}{*}[74]{} \\
\hline & & rs16901816, rs2973644, rs2973646 & Moderate* & \\
\hline & & rs6892212 & Moderate* and severe* & \\
\hline $\mathrm{FKBP}^{\triangle}$ & Penile Hypospadias ${ }^{31}$ & No variants found & Not available & [32] \\
\hline GLII & Not available & $\begin{array}{l}\text { rs } 10783827, \text { rs3825077*, rs3782। } 26, \\
\text { rs2292657, rs4760259, rs2228226 }\end{array}$ & Moderate and severe & [74] \\
\hline GLI2 & $\begin{array}{l}\text { Widely opened urethra and preputial fusion } \\
\text { defects }^{71}\end{array}$ & rs4848I25*, rs4I43II6, rs4848I26* & Moderate & {$[74]$} \\
\hline \multirow[t]{2}{*}{ GLI3 } & No obvious phenotype ${ }^{71}$ & $\begin{array}{l}\text { rs6974655 } \\
\text { rs98862II* }\end{array}$ & $\begin{array}{l}\text { Mild } \\
\text { Severe* and moderate }\end{array}$ & {$[74]$} \\
\hline & & rs380I223 & Moderate & \\
\hline HAAO & $\begin{array}{l}\text { Abnormal seminal vesicle morphology; external } \\
\text { genital phenotype not available }\end{array}$ & rs3816183 & $\begin{array}{l}\text { Anterior/middle and } \\
\text { posterior }\end{array}$ & [106] \\
\hline HOXAI3 & Hypospadias ${ }^{86}$ & Mutation or polyalanine expansions & $\begin{array}{l}\text { Hand-foot-genital } \\
\text { syndrome with } \\
\text { hypospadias not } \\
\text { defined }\end{array}$ & {$[89,90]$} \\
\hline HOXDI3 & Abnormal male accessory sex organs ${ }^{87}$ & Polyalanine duplication at $5^{\prime}$-end & $\begin{array}{l}\text { Distal penile, mid-shaft, } \\
\text { and penoscrotal }(\mathrm{HM}) / \\
\text { Distal }(\mathrm{HZ})\end{array}$ & [88] \\
\hline \multirow[t]{2}{*}{ HOXA4 4} & No obvious phenotype ${ }^{94}$ & rs6962314 & Hypospadias & [95] \\
\hline & & c. $385 \mathrm{G}>\mathrm{T}, \mathrm{c} .869 \mathrm{C}>\mathrm{G}$ & Penoscrotal and penile & {$[80]$} \\
\hline HOXB6 ${ }^{\wedge}$ & No obvious phenotype ${ }^{93}$ & c. $124 \mathrm{C}>\mathrm{A}, \mathrm{c} .367 \mathrm{~T}>\mathrm{C}$ & Scrotal and penile & {$[80]$} \\
\hline \multirow[t]{2}{*}{ HSD3B2 } & Not available & $\mathrm{S} 213 \mathrm{~T}$ & Scrotal & {$[49]$} \\
\hline & & S284R & Midshaft & \\
\hline HSDI7B3 ${ }^{\wedge}$ & Not available & rs2066479 & Hypospadias & {$[50]$} \\
\hline $\operatorname{IRX} 6^{\wedge}$ & Not available & rs6499755 & Anterior/middle & {$[106]$} \\
\hline
\end{tabular}

(Continued) 
Table I (Continued).

\begin{tabular}{|c|c|c|c|c|}
\hline $\begin{array}{l}\text { Gene } \\
\text { Name }\end{array}$ & $\begin{array}{l}\text { Phenotype of EG (or Urogenital System) } \\
\text { in Knockout Male Mice }\end{array}$ & $\begin{array}{l}\text { Gene Variants in Hypospadias } \\
\text { Patients }\end{array}$ & $\begin{array}{l}\text { Clinical Hypospadias } \\
\text { Type }\end{array}$ & Reference \\
\hline INSL3 $^{\Delta}$ & $\begin{array}{l}\text { Bilateral cryptorchidism without obvious penile } \\
\text { phenotype }^{52}\end{array}$ & $\mathrm{C}-19 \mathrm{G}, \mathrm{V} 18 \mathrm{M}$, and $\mathrm{R} 105 \mathrm{H}$ & $\begin{array}{l}\text { Hypospadias with } \\
\text { cryptorchidism }\end{array}$ & {$[53]$} \\
\hline LAMA $^{\Delta}$ & Hypospadias 117 & & Not available & \\
\hline LSMI ${ }^{\wedge}$ & Not available & rs775468919 & Hypospadias & {$[107]$} \\
\hline \multirow[t]{3}{*}{$\begin{array}{l}\text { MAMLDI } \\
(\text { CXorf6) }\end{array}$} & No obvious phenotype ${ }^{54}$ & $\begin{array}{l}c .370 G \rightarrow T(E \mid 24 X), c .589 C \rightarrow T \\
(Q 197 X), c .1957 C \rightarrow T(R 653 X)\end{array}$ & Penoscrotal & {$[56]$} \\
\hline & & c. $1295 \mathrm{~T}>\mathrm{C}(\mathrm{V} 432 \mathrm{~A}), 325 \mathrm{del} \mathrm{G}$ & $\begin{array}{l}\text { Penoscrotal and } \\
\text { proximal }\end{array}$ & {$[55]$} \\
\hline & & $\mathrm{CAG}_{10} \rightarrow \mathrm{CAG}_{13}$ & Subcoronal & \\
\hline $\mathrm{MTHFR}^{\boldsymbol{\Delta}}$ & Not available & C677T & Middle and posterior & {$[109]$} \\
\hline $\operatorname{MIDI}{ }^{\wedge}$ & No urogenital abnormalities ${ }^{1 / 3}$ & $\begin{array}{l}\text { c. } 7 \mid 2 G>T, c .1679 A>G, \text { c. } 1230 G>A \\
(|230 A, r s| 6986 \mid 45)\end{array}$ & Hypospadias & {$[108]$} \\
\hline MYRF $^{\wedge}$ & Not available & c. $2336+I G>A$ & Penoscrotal & {$[110]$} \\
\hline \multirow[t]{2}{*}{$\begin{array}{l}\text { NR5AI/ } \\
\text { SFI }\end{array}$} & $\begin{array}{l}\text { Abnormal gonad and adrenal gland } \\
\text { development }{ }^{58}\end{array}$ & $\begin{array}{l}(\text { CTGCAGCTG }) \times 2 \\
\text { c. } 74 A>G \\
\text { c. } 814 A>C\end{array}$ & $\begin{array}{l}\text { Severe proximal } \\
\text { Penoscrotal } \\
\text { Ambiguous genitalia }\end{array}$ & {$[63,64,66]$} \\
\hline & & c. $319 \mathrm{C}>\mathrm{T}$, c. $103-3 \mathrm{C}>\mathrm{A}$, c. $31 \mathrm{G}>\mathrm{T}$ & Penoscrotal/scrotal & {$[65]$} \\
\hline $\mathrm{PGK} 2 \Delta$ & No obvious phenotype & STR in the $3^{\prime}$ flanking region & Perineal & {$[\mathrm{III}]$} \\
\hline $\mathrm{SHH}^{\Delta}$ & Agenesis $^{72}$ or hypospadias ${ }^{70}$ & rs9333613 & Moderate & [74] \\
\hline SMADIPI & Not available & 935delG, deletion & $\begin{array}{l}\text { Hypospadias and } \\
\text { agenesis } \\
\text { of the corpus callosum }\end{array}$ & {$[112]$} \\
\hline $\begin{array}{l}\mathrm{SPRYI}^{\Delta} \text { and } \\
\mathrm{SPRY}^{\Delta}\end{array}$ & $\begin{array}{l}\text { Absence of internal tubular urethra, and } \\
\text { hypospadias-like phenotype }^{76}\end{array}$ & & Not available & \\
\hline \multirow[t]{4}{*}{ SRD5A2 } & No obvious phenotype ${ }^{41}$ & V89L (rs523349), A49T (rs9282858) & Hypospadias & {$[43]$} \\
\hline & & $\begin{array}{l}\text { c. } 168 \mathrm{G}>\mathrm{C}, \mathrm{p} . \mathrm{V} 89 \mathrm{~L} \\
\text { rs } 7562326\end{array}$ & $\begin{array}{l}\text { Severe perineoscrotal } \\
\text { Penoscrotal }\end{array}$ & {$[42,44]$} \\
\hline & & c. $123 \mathrm{G}>\mathrm{A}$ & Perineoscrotal & {$[45]$} \\
\hline & & $\begin{array}{l}\text { c. } 16 \mathrm{C}>\mathrm{T}, \mathrm{c} .21 \mathrm{I} \mathrm{C}>\mathrm{T}, \mathrm{c} .59 \mathrm{~T}>\mathrm{C}, \\
\text { c. } 586 \mathrm{G}>\mathrm{C}, \mathrm{c} .607 \mathrm{G}>\mathrm{A}, \mathrm{c} .680 \mathrm{G}>\mathrm{A}, \\
\text { c. } 737 \mathrm{G}>\mathrm{A}, 218 \mathrm{delT}\end{array}$ & Posterior & [46] \\
\hline $\mathrm{SRY}^{\mathbf{\Delta}}$ & Sex reversal ${ }^{59}$ & mosaic $S R Y$ mutation & $\begin{array}{l}\text { Hypospadias and } \\
\text { cryptorchidism }\end{array}$ & {$[67]$} \\
\hline STARD3 ${ }^{\wedge}$ & Not available & rs I87703। & Penoscrotal & {$[42]$} \\
\hline \multirow[t]{2}{*}{ STS ${ }^{\wedge}$} & Not available & $\begin{array}{l}\text { rs5934740, rs5934842, rs59349I3, } \\
\text { rs66398II, rs392334I, rsI7268974, } \\
\text { rs5934937 }\end{array}$ & Penoscrotal & {$[42]$} \\
\hline & & rsI7268974 & Penile & \\
\hline
\end{tabular}

(Continued) 
Table I (Continued).

\begin{tabular}{|c|c|c|c|c|}
\hline $\begin{array}{l}\text { Gene } \\
\text { Name }\end{array}$ & $\begin{array}{l}\text { Phenotype of EG (or Urogenital System) } \\
\text { in Knockout Male Mice }\end{array}$ & $\begin{array}{l}\text { Gene Variants in Hypospadias } \\
\text { Patients }\end{array}$ & $\begin{array}{l}\text { Clinical Hypospadias } \\
\text { Type }\end{array}$ & Reference \\
\hline TGFBR2 ${ }^{\wedge}$ & $\begin{array}{l}\text { Increased prostate gland adenocarcinoma and } \\
\text { intraepithelial neoplasia incidence; penile } \\
\text { phenotype not available } \\
83\end{array}$ & rs6785358 (G allele) & Hypospadias & [82] \\
\hline WTI ${ }^{\wedge}$ & $\begin{array}{l}\text { Deletion causes the failure of gonad and kidney } \\
\text { development, } \\
\text { no gross abnormalities of EG were observed in } \\
\text { conditional knockout males }^{61}\end{array}$ & $\begin{array}{l}\text { rsl799937, rs5030277, rs3858449, } \\
\text { rs5030234 } \\
\text { rsl } 6574 \\
\text { rs } 12293750\end{array}$ & $\begin{array}{l}\text { Severe } \\
\text { Severe and mild } \\
\text { Mild }\end{array}$ & [74] \\
\hline
\end{tabular}

Notes: ${ }^{*}$ The risk was restricted to non-Hispanic whites. ${ }^{\#}$ The risk was restricted to Hispanics. ${ }^{\Delta}$ or ${ }^{\Delta}$. The hypospadias related genes were first identified from human patients $\left({ }^{\Delta}\right)$ or mutant mice $\left({ }^{\Delta}\right)$. "Not available" for mutant mouse phenotypes indicates either the phenotypes of EG in mutant male mice have not been recorded, or the mutant mouse strains are not available; for clinical hypospadias type indicates no relevant studies have been reported. If the severity of the human hypospadias was not defined, we use "hypospadias". Deletion regions involving multiple genes are not included.

Androgen masculinizes genital development through AR. Male mice with mutations in $A r$ gene develop feminized external genitalia (EG), ${ }^{24}$ and disrupting AR in the androgen sensitive time window induces hypospadias. ${ }^{25}$ In humans, mutations in $A R$ underlie different forms of androgen insensitivity syndrome. ${ }^{26}$ Polymorphism in $A R$ gene contributes to susceptibility to severe hypospadias. Point mutation in exon 7 causes perineal or scrotal hypospadias. ${ }^{27}$ Adamovic and Nordenskjold ${ }^{28}$ have provided evidence that a higher number of the CAG repeat in the sequence of $A R$ gene has a clear effect on the risk of hypospadias in Caucasians, while some other literature reported that there was no significant difference in CAG length between cases with hypospadias and controls in Japanese. ${ }^{29}$ GGN repeat is another polymorphism of $A R$ gene and was found to be associated with hypospadias in Iranians and Swedes, whereas the length of CAG repeat showed no significant difference between hypospadias cases and controls in the same group. ${ }^{30}$ FK506-binding protein 4 (FKBP4) gene, also known as FKBP52, is an important AR activator, male mice with targeted ablation of $F k b p 4$ develop hypospadias, ${ }^{31}$ but no mutation was found in hypospadias patients. $^{32}$ The varieties of the populations and sample sizes may account for the inconsistency of the results. Clearly, the polymorphism of $A R$ is complicated, and large sample sizes are necessary for the future studies in humans.

Estrogen receptor (ESR) has two major isoforms, ESR1 and ESR2. Deletion of either of them or double knockout caused no obvious external genital phenotype in mice. ${ }^{33}$ But single nucleotide polymorphisms (SNPs) of ESR1 and ESR2 in humans were reported to have significant relationship with hypospadias. ${ }^{34}$ Watanabe et $\mathrm{al}^{35}$ have reported that the frequency of "AGATA" haplotype of ESR1 is significantly higher in patients with hypospadias than in controls, which may enhance the ESR1 signaling and finally facilitate the development of hypospadias in the Japanese population. ESR2 is expressed in fetal and adult testes. ${ }^{36}$ The CA repeat in ESR2 was found to be significantly prolonged in hypospadias patients compared with the controls, and the genetic variant of rs944050 in the heterozygous form in ESR2 was more frequent in hypospadias patients than in controls. $^{37,38}$ Although deletion of Esrl and Esr2 in mice has not shown detectable phenotypic change in EG, prenatal estrogen treatment in mice dramatically reduces penile size and induces a phenotype similar to human micropenis, ${ }^{25,39}$ and there has been more evidence of estrogen's detrimental effects on penile masculinization; sequence variations in estrogen receptors may contribute to the development of hypospadias through increasing estrogen signaling. And, given genetic polymorphisms such as SNPs in hypospadias patients are variable, we think more data from hypospadias patients are necessary to draw clear conclusions.

The mutation of steroid 5 alpha reductase (SRD5A), especially $S R D 5 A 2$, is one of the main causes of pseudohermaphroditism in humans. ${ }^{40}$ Interestingly, male $\mathrm{Srd} 5 \mathrm{a} 2$ knockout or Srd5al and Srd5a2 double knockout mice show fully formed EG. ${ }^{41}$ As many different SNPs or mutations of human $S R D 5 A 2$ have been reported to correlate with severe hypospadias, ${ }^{42-46}$ we believe different mechanism may exist in action of DHT in penile urethral development between humans and mice.

Steroidogenic genes also play important roles in normal genital development and sex differentiation. It has been known that deletion of cytochrome P450 family 11 subfamily A member 1 (Cyp11al) induces to form female 
EG in male mice, ${ }^{47}$ but no study on external genital development in steroid sulfatase (Sts), hydroxy-delta -5-steroid dehydrogenase (Hsd3b2), hydroxysteroid 17beta dehydrogenase 3 (Hsd17b3), Hsd17b5, or StAR related lipid transfer domain containing 3 (Stard3) gene knockout mice has been reported, although in humans, genetic variations in these genes have been found to be associated with different types of hypospadias. ${ }^{42,48-51}$ Insulin-like hormone 3 (INSL3) gene, another Leydigassociated gene encoding a member of the insulin-like hormone superfamily produced mainly in gonadal tissues, was proved to be a cryptorchidism causal gene in mice, ${ }^{52}$ mutations of this gene in humans were identified to be associated with cryptorchidism, and maybe hypospadias and micropenis as well. ${ }^{53}$

In addition, mastermind like domain containing 1 (MAMLD1), also known as chromosome $\mathrm{X}$ open reading frame 6 (CXorf6), is a causative gene for 46,XY disorders of sex development with hypospadias as a salient clinical phenotype and involved in the testosterone production, but mutant male mice exhibit normal genital and reproductive development. ${ }^{54}$ Polymorphisms of this gene in humans are highly associated with hypospadias. ${ }^{55,56}$ Ratan et al ${ }^{57}$ indicated that Indian boys with isolated hypospadias had significantly higher incidence of $M A M L D 1$ polymorphism than a control group.

Genetic sex determination pathway genes control sex determination and gonad development, deletion of sexdetermining region $\mathrm{Y}(S r y)$, the steroidogenic factor 1 $(S f-1)$ or Wilms tumor $1(W t 1)$ in mice induces abnormal gonad development or male-to-female sex reversal. ${ }^{58-61}$ It has been revealed that human mutations in any one of these genes cause impaired testis development, ${ }^{62}$ and some of the genetic variations or duplications in these sex determination genes also induce severe hypospadias, but these hypospadias patients usually have other reproductive organ defects ${ }^{63-67}$ (Table 1).

Most early external genital developmental genes also play important roles during sex differentiation. Deletion of any one of the fibroblast growth factor pathway genes Fgf10, Fgfr2, or hedgehog pathway genes Shh, Gli2, and Gli3 in mice induces hypospadias. ${ }^{68-72}$ And SNPs of these genes and some other genes in the same pathways, such as GLI1, have been found in hypospadias patients. ${ }^{73,74} \mathrm{Fg} f 8$ knockout mice form normal EG, ${ }^{75}$ however SNPs in $F G F 8$ in hypospadias patients have been reported, ${ }^{73}$ which may suggest the different function of this gene in external genital development between humans and mice, but further investigation on larger sampling is required to clarify the causal role of $F G F 8$ in the development of hypospadias in humans. Sprouty $(S P R Y)$ genes are critical regulators of FGF signaling during embryonic patterning of the male GT, and the combined deletion of Spryl and Spry2 in the male mouse embryo affected genital morphogenesis. ${ }^{76}$ Until now, the variation of SPRY1 or $S P R Y 2$ in hypospadias patients has never been reported. In addition, deletion of bone morphogenetic protein pathway genes $B m p 4, B m p 7$, or $\mathrm{Wnt} / \beta$-catenin signaling genes, such as Ctnnb1, can also induce external genital malformation including hypospadias in mice. ${ }^{77-79}$ As expected, polymorphisms of all these genes, and transforming growth factor beta receptor 2 (TGFBR2) as well, have been detected in hypospadias patients, ${ }^{74,80-82}$ although no obvious penile phenotype was observed in $T g f b r 2$ knockout mice. ${ }^{83}$ EPHRIN-B2 and its receptor EPHB2 play major roles in cell adhesion and tubular urethra formation, and male mice carrying the mutations develop severe hypospadias and incomplete midline fusion of the primitive cloaca. ${ }^{84}$ How these early developmental genes interact with steroid hormone signaling and how they regulate sexual differentiation are interesting questions.

Hox genes regulate the vertebrate body plan. ${ }^{85}$ Several Hox genes such as Hoxal3 and Hoxd13 are strongly expressed in developing EG, and deletion of them in mice causes hypospadias or male accessory sex organ malformation. ${ }^{86,87}$ Mutation of $H O X A 13$ or polyalanine expansions in this gene in humans results in hand-footgenital syndrome with hypospadias of variable severity in male patients, and mutation in human $H O X D 13$ can also lead to hypospadias in various forms in males. ${ }^{88-90}$ Hoxa 4 gene was found to be expressed in mouse testis, ${ }^{91}$ and Hoxb6 may be expressed in male reproductive organs. ${ }^{92}$ No obvious phenotypic change in reproductive organs has been observed in mutant mice deficient in either Hoxa 4 or Hoxb6, ${ }^{93,94}$ but genetic variants of both genes have been found to be associated with human hypospadias. ${ }^{80,95}$ Empty spiracles homeobox 2 (Emx2) gene is a transcriptional target of HOXA10 regulation in the reproductive tract, ${ }^{96,97}$ mutation of this homeobox gene in humans induces hypospadias and concomitant other genital malformations. ${ }^{98}$ More patient research is required to understand the roles of HOX genes and other homeobox genes in hypospadias malformation.

Activating transcription factor 3 (ATF3) is upregulated in penile tissue in hypospadias patients and estrogen-treated mice. ${ }^{99}$ Atf3 knockout mice are available, but no external genital phenotype has been reported. ${ }^{100}$ We assume that 
maybe there is no obvious external genital phenotype in Atf3 knockout mice. However, in humans, the variants of $A T F 3$ have been identified as risk factors for hypospadias. ${ }^{101}$

Variants in human $B N C 2,{ }^{102} C H D 11,{ }^{103} D G K K,{ }^{104,105}$ HAAO and IRX6, ${ }^{106}$ LSM $^{107}{ }^{107}$ MID1, ${ }^{108}$ MTHFR, ${ }^{109}$ $M Y R F,{ }^{110} P G K 2,{ }^{111}$ SMADIP1, ${ }^{112}$ and some other genes have also been reported to be associated with hypospadias. Although distal urethral defects were observed in Bnc2 knockout newborn mice, ${ }^{102}$ no urogenital abnormalities were present in Midl knockout mice, ${ }^{113}$ and also no external genital phenotype has been reported in Cdh11, ${ }^{114} \mathrm{Dgkk}$, Haao, ${ }^{115}$ Lsm1, Myrf, Pkg2, ${ }^{116}$ or Irx6 knockout mice. In addition, Lama5 was found to be required for urethral and external genital development, and deletion of Lama5 induced hypospadias in mice, suggesting it may be a potential hypospadias causal gene; ${ }^{117}$ until now, no SNP or mutation of $L A M A 5$ has been reported in hypospadias patients (Table 1).

\section{Only a Small Portion of the Human Hypospadias Related Gene Mutations Have Been Reported to Show Similar Phenotypes in Mutant Mice}

In the 49 hypospadias related genes we listed in Table 1, the majority of them (41) were first identified from human patients. Mutations in 13 out of the 49 genes were shown to cause hypospadias in mice (Figure 1), thus far, only mutations in seven out of the 13 genes $(A R, B N C 2$, CTNNB1, FGFR2, FGF10, HOXA13, and SHH) have been associated with an increased risk of hypospadias in humans, variations of the other six genes (EPHRIN-B2, EPHB2, FKBP4, LAMA5, SPRY1, and SPRY2) have not yet been identified in human hypospadias patients, we suggest more investigations of the association between genetic variance of these genes and hypospadias risk should be conducted in hypospadias patients. Among the 43 human hypospadias related genes we listed in Table 1 (at least one mutation or polymorphism of the gene has been reported to be associated with hypospadias in groups of patients) (Figure 1), only mutations in seven genes $(A R$, BNC2, CTNNB1, FGFR2, FGF10, HOXA13, and SHH) have been shown to cause hypospadias in both humans and mice, no typical hypospadias but other or even more severe urogenital anomalies were observed in the knockout male mice of 12 genes (BMP4, BMP7, CYP11A1, EMX2, GLI2, HAAO, HOXD13, INSL3, NR5A1/SF1, $S R Y, T G F B R 2$, and $W T 1)$, male mice deficient in 12 genes (ATF3, CDH11, ESR1, ESR2, FGF8, GLI3, HOXA4, HOXB6, MAMLD1, MID1, PKG2, and $S R D 5 A 2)$ displayed no obvious phenotypic external genital abnormalities, and data of the external genital development in mouse mutants of the remaining 12 human hypospadias related genes $(A K R 1 C 3, D G K K, G L I 1, H S D 3 B 2$,

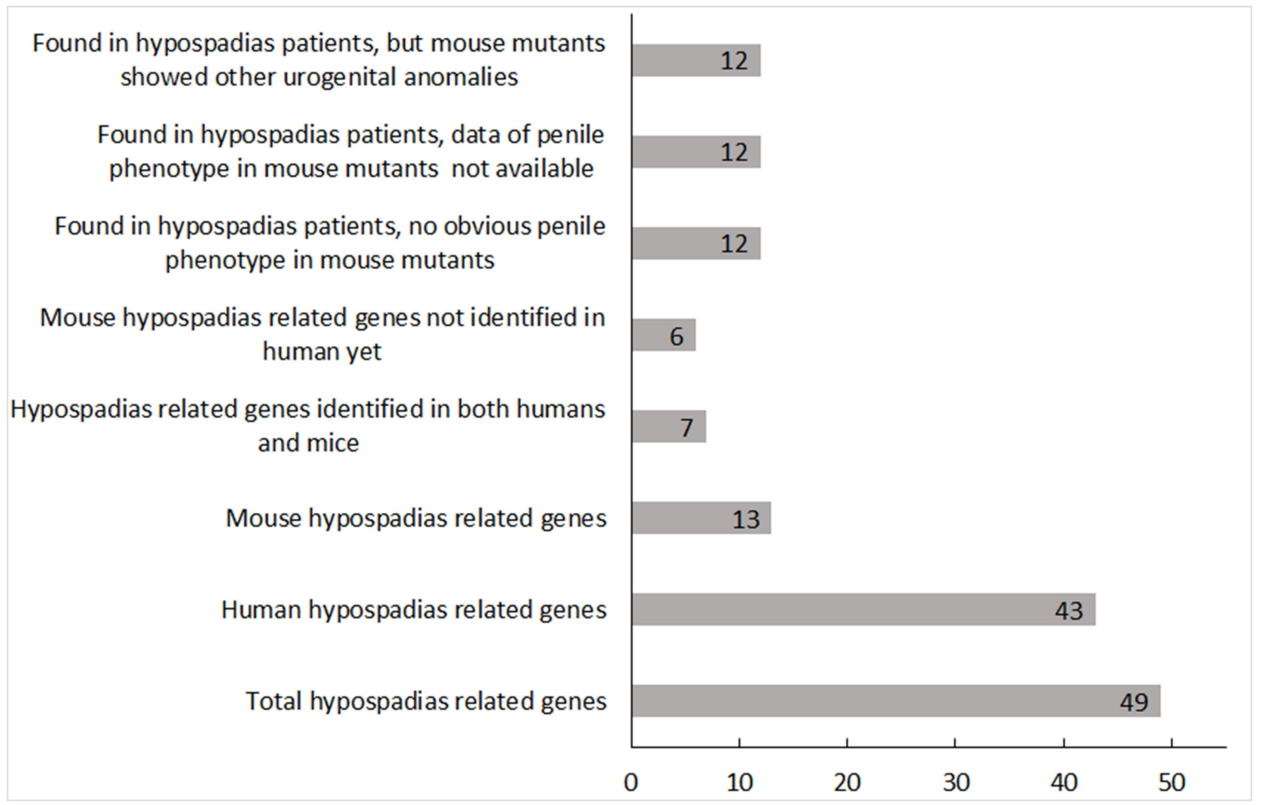

Figure I Genetic mutations found in hypospadias patients and mice. The figure shows the numbers of gene mutations found so far in hypospadias patients and mice. The $x$-axis indicates the number of genes, and the $y$-axis indicates the different groups. All the data were based on publications and online resources before September I, 2020. 
HSD17B3, IRX6, LSM1, MTHFR, MYRF, SMADIPI, $S T A R D 3$, and $S T S$ ) are still not available. There may be multiple reasons for the phenotypic differences caused by these gene mutations between mice and humans, the differences in the mechanisms of external genital development and hypospadias malformation between the two species are likely to be the main reasons.

\section{Other Animal Models in Studies of the Etiology of Hypospadias}

Mouse is the most commonly used animal model to investigate the etiology of hypospadias. However, due to the difference in the developmental mechanisms of penile urethra between mice and humans, mid-shaft or perineal hypospadias has only been observed in human hypospadias patients but never seen in mice. ${ }^{118}$ Except for mice, rats have also been widely used in hypospadias related research, but the majority of the studies focused on the effect of environmental endocrine disrupting chemicals. ${ }^{119,120}$ Hypospadias related genetic mutation in rats has never been reported. The detailed comparison of mice, rats, and humans was reviewed by Cunha et al, ${ }^{118}$ and they suggested that mouse and rat models do not fully reflect the human condition. Rabbits are another useful model for hypospadias, and the fetal development of the rabbit phallus is relatively more analogous to that of the human. ${ }^{15} \mathrm{~A}$ literature search suggests that the rabbit model is more commonly used for hypospadias repair studies, rather than for etiologic research of hypospadias. ${ }^{121}$

Hypospadias were also found in other domestic animals such as dogs, ${ }^{122}$ cats, ${ }^{123}$ sheep, ${ }^{124}$ cattle, ${ }^{125}$ and horses. ${ }^{126}$ Moreover, polymorphisms were also found in MAMLD1, SRD5A2, and $A R$ genes in hypospadias dogs. ${ }^{127}$ Mice mutant for Insl3 has no obvious penile phenotype, but the dogs with a heterozygous base change in INSL3 gene showed similar hypospadias and cryptorchidism phenotypes to those of human $\mathrm{C}-19 \mathrm{G}, \mathrm{V} 18 \mathrm{M}$, or $\mathrm{R} 105 \mathrm{H}$ variants. ${ }^{52,53,128}$ Dogs are the most widely used domestic animal model for hypospadias research, and the majority of the hypospadias studies using domestic animal models were case reports, ${ }^{129,130}$ or focused on surgical repair. ${ }^{131}$

\section{Guinea Pig Is Another Optional Animal Model to Study Human Penile Development and Hypospadias}

Appropriate animal models are important to study penile development and hypospadias. In humans, the male genital tubercle development involves an initial opening of the urethral plate to form a urethral groove from proximal to distal, and subsequent fusion of the proximal region to close the urethral and penile epithelia and extend the closed urethra distally (distal opening proximal closing zipper). Females show a similar urethral plate opening to form a urethral groove, but lack the following urethral closure seen in males (the single opening zipper), both males and females form urethral grooves before sex differentiation and tubular urethra formation. ${ }^{132,133}$ In commonly used mice and rats, the penile tubular urethra forms by direct canalization of the urethral plate within the penis body ${ }^{134-136}$ without forming an obvious urethral groove, ${ }^{137}$ moreover, the penile urethral closing from proximal to distal accomplishes during embryonic development ${ }^{14,132}$ in humans, but the process still continues after birth in mice and rats. ${ }^{138}$

Guinea pig has been used as an effective model to study sexual differentiation and the role of exogenous and endogenous steroid hormones in sexually dimorphic organ and behavioral development since decades before. ${ }^{14,-139-141}$ Wang et al ${ }^{14}$ elucidated the embryonic early development and sex differentiation of guinea pig EG and the pharmaceutical induction of male hypospadias and female penis in guinea pigs, revealing that fetal development of the guinea pig phallus is homologous to that of humans; the key steps in human external genital development, urethral groove formation (in both sexes), and subsequent "distal opening and proximal closing" (in males), which have never been shown in commonly used animal models such as mice and rats, were presented in guinea pigs; antiandrogen bicalutamide treatment in different time periods around the urethral tube closing stage successfully induced hypospadias with various severity in guinea pigs, the phenotypes were similar to those of human hypospadias (eg, penosrotal hypospadias); compared to mice and rats, guinea pigs have a relatively longer gestation (on average 68 days), the EG of newborn guinea pigs is well developed, and the antiandrogen-induced hypospadias phenotypes can be detected at birth, suggesting the key sexual differentiation process of the guinea pig EG occurs prenatally as well as that of humans; the findings suggest that the guinea pig is a good model to study the mechanisms of human penile urethral formation (eg, distal opening and proximal closing) and to evaluate the pathophysiological processes of hypospadias. In addition, Wang and Zheng ${ }^{142}$ showed the differential expression pattern of Shh between the guinea pigs during urethral 
groove formation and the mice at the comparable stage: Shh mRNA expression domain shifts out to the ventral surface of genital tubercle from proximal throughout to distal in guinea pigs, but is excluded from the ventral surface epithelium in midshaft and distal of mouse genital tubercle; suggested Shh expression in ventral surface epithelium of genital tubercle may play a causal role in urethral groove formation in guinea pigs, maybe in humans as well. Although the penile development in guinea pigs is similar to that in humans at early tubular urethral forming stage, there are some differences in the urethral closure process and penile development between guinea pigs and humans at later embryonic and postnatal stages, eg, guinea pigs, but not humans, form a baculum before birth, and develop penile spines after birth. ${ }^{14}$ Nevertheless, the literature studying hypospadias based on a guinea pig model is still very limited.

\section{Conclusion and Future Directions}

In general, the knowledge about genetic factors underlying hypospadias is very limited, and the majority of variants discovered in hypospadias patients did not show similar phenotypes in mouse mutants. As we know, most genetic polymorphisms in hypospadias patients were identified by single gene sequencing, not considering whether the other gene(s) had sequence variants or not meanwhile. As technologies are available, and the genome sequencing is getting cheaper, whole genome sequencing of hypospadias patients should be performed in the future to reveal hypospadias causal genes in humans. The environmental factors may induce hypospadias through affecting developmental gene expression, which can be detected by transcriptome sequencing (RNA-seq), but the up or down expression levels of the affected genes may not be detected in hypospadias patients after birth; to understand the deep mechanisms of hypospadias, reliable animal models are required. We need to understand the similarities and differences in the processes of penile development and hypospadias malformation among humans, mice, and other animal models, and carefully select animal models based on specific research questions. For studies of mechanisms of urethral groove formation and the "distal opening and proximal closing" in tubular urethral formation, guinea pig may be one good choice.

\section{Funding}

The study was partially supported by Eunice Kennedy Shriver National Institute of Child Health and Human Development (R15HD095368).

\section{Disclosure}

All authors declare they have no conflict of interest.

\section{References}

1. Nelson CP, Park JM, Wan J, Bloom DA, Dunn RL, Wei JT. The increasing incidence of congenital penile anomalies in the United States. $J$ Urol. 2005;174(4):1573-1576. doi:10.1097/01. ju.0000179249.21944.7e

2. Baskin L. What is hypospadias? Clin Pediatr (Phila). 2017;56 (5):409-418. doi:10.1177/0009922816684613

3. Manson JM, Carr MC. Molecular epidemiology of hypospadias: review of genetic and environmental risk factors. Birth Defects Res a Clin Mol Teratol. 2003;67(10):825-836. doi:10.1002/ bdra. 10084

4. Holmes NM, Miller WL, Baskin LS. Lack of defects in androgen production in children with hypospadias. $J$ Clin Endocrinol Metab. 2004;89(6):2811-2816. doi:10.1210/jc.2003-032098

5. Vilela MLB, Willingham E, Buckley J, et al. Endocrine disruptors and hypospadias: role of genistein and the fungicide vinclozolin. Urology. 2007;70(3):618-621. doi:10.1016/j.urology.2007.05.004

6. Zhao S, Li D, Bei X-Y, et al. Maternal exposure to di-n-butyl phthalate (DBP) promotes epithelial-mesenchymal transition via regulation of autophagy in uroepithelial cell. Toxicology. 2018;406:114-122. doi:10.1016/j.tox.2018.07.013

7. Cunha GR, Sinclair A, Ricke WA, Robboy SJ, Cao M, Baskin LS. Reproductive tract biology: of mice and men. Differentiation. 2019;110:49-63.

8. Bouty A, Ayers KL, Pask A, Heloury Y, Sinclair AH. The genetic and environmental factors underlying hypospadias. Sex Dev. 2015;9(5):239-259. doi:10.1159/000441988

9. Blaschko SD, Cunha GR, Baskin LS. Molecular mechanisms of external genitalia development. Differentiation. 2012;84 (3):261-268.

10. Cohn MJ. Development of the external genitalia: conserved and divergent mechanisms of appendage patterning. Dev Dyn. 2011;240(5):1108-1115. doi:10.1002/dvdy.22631

11. Ipulan LA, Suzuki K, Matsushita S, et al. Development of the external genitalia and their sexual dimorphic regulation in mice. Sex Dev. 2014;8(5):297-310. doi:10.1159/000357932

12. Phillips TR, Wright DK, Gradie PE, Johnston LA, Pask AJ. A comprehensive atlas of the adult mouse penis. Sex Dev. 2015;9(3):162-172. doi:10.1159/000431010

13. Sinclair AW, Cao M, Pask A, Baskin L, Cunha GR. Flutamideinduced hypospadias in rats: a critical assessment. Differentiation. 2017;94:37-57. doi:10.1016/j.diff.2016.12.001

14. Wang S, Shi M, Zhu D, Mathews R, Zheng Z. External genital development, urethra formation, and hypospadias induction in guinea pig: a double zipper model for human urethral development. Urology. 2018;113:179-186. doi:10.1016/j. urology.2017.11.002

15. Kurzrock EA, Jegatheesan P, Cunha GR, Baskin LS. Urethral development in the fetal rabbit and induction of hypospadias: a model for human development. $J$ Urol. 2000;164 (5):1786-1792. doi:10.1016/S0022-5347(05)67107-8

16. Switonski M, Payan-Carreira R, Bartz M, et al. Hypospadias in a male (78,XY; SRY-positive) dog and sex reversal female (78, $\mathrm{XX}$; SRY-negative) dogs: clinical, histological and genetic studies. Sex Dev. 2012;6(1-3):128-134. doi:10.1159/000330921

17. Lowry RB, Kliman MR. Hypospadias in successive generations-possible dominant gene inheritance. Clin Genet. 1976;9(3):285-288. doi:10.1111/j.1399-0004.1976.tb01576.x

18. Schnack TH, Zdravkovic S, Myrup C, et al. Familial aggregation of hypospadias: a cohort study. Am J Epidemiol. 2008;167 (3):251-256. doi:10.1093/aje/kwm317 
19. Bauer SB, Bull MJ, Retik AB. Hypospadias-familial study. J Urol. 1979;121(4):474-477.

20. Stoll C, Alembik Y, Roth MP, Dott B. Genetic and environmental-factors in hypospadias. J Med Genet. 1990;27 (9):559-563. doi:10.1136/jmg.27.9.559

21. Vottero A, Minari R, Viani I, et al. Evidence for epigenetic abnormalities of the androgen receptor gene in foreskin from children with hypospadias. J Clin Endocrinol Metab. 2011;96 (12):E1953-E1962. doi:10.1210/jc.2011-0511

22. Ohsako S, Aiba T, Miyado M, et al. Expression of xenobiotic biomarkers CYP1 family in preputial tissue of patients with hypospadias and phimosis and its association with DNA methylation level of SRD5A2 minimal promoter. Arch Environ Contam Toxicol. 2018;74(2):240-247. doi:10.1007/s00244-017-0466-x

23. Choudhry S, Deshpande A, Qiao L, Beckman K, Sen S, Baskin LS. Genome-wide DNA methylation profiling of $\mathrm{CpG}$ islands in hypospadias. $J$ Urol. 2012;188(4):1450-1455. doi:10.1016/j.juro.2012.03.047

24. Lyon MF, Hawkes SG. X-linked gene for testicular feminization in the mouse. Nature. 1970;227(5264):1217-1219. doi:10.1038/ $2271217 \mathrm{a} 0$

25. Zheng Z, Armfield BA, Cohn MJ. Timing of androgen receptor disruption and estrogen exposure underlies a spectrum of congenital penile anomalies. Proc Natl Acad Sci U S A. 2015;112(52): E7194-7203. doi:10.1073/pnas.1515981112

26. Hughes IA, Davies JD, Bunch TI, Pasterski V, Mastroyannopoulou K, MacDougall J. Androgen insensitivity syndrome. Lancet. 2012;380(9851):1419-1428. doi:10.1016/ S0140-6736(12)60071-3

27. Wang YP, Li Q, Xu JJ, et al. Mutation analysis of five candidate genes in Chinese patients with hypospadias. Eur J Hum Genet. 2004;12(9):706-712. doi:10.1038/sj.ejhg.5201232

28. Adamovic T, Nordenskjold A. The CAG repeat polymorphism in the androgen receptor gene modifies the risk for hypospadias in Caucasians. BMC Med Genet. 2012;13.

29. Muroya K, Sasagawa I, Suzuki Y, Nakada T, Ishii T, Ogata T. Hypospadias and the androgen receptor gene: mutation screening and CAG repeat length analysis. Mol Hum Reprod. 2001;7 (5):409-413. doi:10.1093/molehr/7.5.409

30. Aschim EL, Nordenskjold A, Giwercman A, et al. Linkage between cryptorchidism, hypospadias, and GGN repeat length in the androgen receptor gene. J Clin Endocrinol Metab. 2004;89 (10):5105-5109. doi:10.1210/jc.2004-0293

31. Yong W, Yang Z, Periyasamy S, et al. Essential role for co-chaperone Fkbp52 but not Fkbp51 in androgen receptor-mediated signaling and physiology. $J$ Biol Chem. 2007;282(7):5026-5036. doi:10.1074/jbc.M609360200

32. Beleza-Meireles A, Barbaro $M$, Wedell A, Tohonen V, Nordenskjold A. Studies of a co-chaperone of the androgen receptor, FKBP52, as candidate for hypospadias. Reprod Biol Endocrinol. 2007;5(1):8. doi:10.1186/1477-7827-5-8

33. Dupont S, Krust A, Gansmuller A, Dierich A, Chambon P, Mark M. Effect of single and compound knockouts of estrogen receptors alpha (ERalpha) and beta (ERbeta) on mouse reproductive phenotypes. Development. 2000;127(19):4277-4291.

34. Ban S, Sata F, Kurahashi N, et al. Genetic polymorphisms of ESR1 and ESR2 that may influence estrogen activity and the risk of hypospadias. Hum Reprod. 2008;23(6):1466-1471. doi:10.1093/humrep/den098

35. Watanabe M, Yoshida R, Ueoka K, et al. Haplotype analysis of the estrogen receptor 1 gene in male genital and reproductive abnormalities. Hum Reprod. 2007;22(5):1279-1284. doi:10.1093/humrep/del513

36. O'donnell L, Robertson KM, Jones ME, Simpson E. Estrogen and spermatogenesis. Endocr Rev. 2001;22(3):289-318.
37. Beleza-Meireles A, Omrani D, Kockum I, Frisen L, Lagerstedt K, Nordenskjold A. Polymorphisms of estrogen receptor beta gene are associated with hypospadias. J Endocrinol Invest. 2006;29 (1):5-10. doi:10.1007/BF03349170

38. van der Zanden LFM, van Rooij IALM, Feitz WFJ, et al. Genetics of hypospadias: are single-nucleotide polymorphisms in SRD5A2, ESR1, ESR2, and ATF3 really associated with the malformation? J Clin Endocrinol Metab. 2010;95(5):2384-2390. doi:10.1210/jc.2009-2101

39. Goyal H, Braden T, Cooke P, et al. Estrogen receptor- $\alpha$ mediates estrogen-inducible abnormalities in the developing penis. Reproduction. 2007;133(5):1057-1067. doi:10.1530/REP-060326

40. Thigpen AE, Davis DL, Milatovich A, et al. Molecular genetics of steroid 5 alpha-reductase 2 deficiency. $J$ Clin Invest. 1992;90 (3):799-809. doi:10.1172/JCI115954

41. Mahendroo MS, Cala KM, Hess DL, Russell DW. Unexpected virilization in male mice lacking steroid 5 alpha-reductase enzymes. Endocrinology. 2001;142(11):4652-4662. doi:10.1210/ endo.142.11.8510

42. Singh N, Gupta DK, Sharma S, et al. Single-nucleotide and copy-number variance related to severity of hypospadias. Pediatr Surg Int. 2018;34(9):991-1008. doi:10.1007/s00383018-4330-5

43. Rahimi M, Ghanbari M, Fazeli Z, et al. Association of SRD5A2 gene mutations with risk of hypospadias in the Iranian population. $J$ Endocrinol Invest. 2017;40(4):391-396. doi:10.1007/s40618016-0573-y

44. Sahu R, Boddula R, Sharma P, et al. Genetic analysis of the SRD5A2 gene in Indian patients with 5 alpha-reductase deficiency. J Pediatr Endocrinol Metab. 2009;22(3):247-254.

45. Bahceci M, Ersay AR, Tuzcu A, Hiort O, Richter-Unruh A, Gokalp D. A novel missense mutation of 5-alpha reductase type 2 gene (SRD5A2) leads to severe male pseudohermaphroditism in a Turkish family. Urology. 2005;66(2):407-410. doi:10.1016/j. urology.2005.02.021

46. Yuan S, Meng L, Zhang Y, et al. Genotype-phenotype correlation and identification of two novel SRD5A2 mutations in 33 Chinese patients with hypospadias. Steroids. 2017;125:61-66. doi:10.1016/j.steroids.2017.06.010

47. Hu MC, Hsu NC, El Hadj NB, et al. Steroid deficiency syndromes in mice with targeted disruption of Cyp11a1. Mol Endocrinol. 2002;16(8):1943-1950. doi:10.1210/me.2002-0055

48. Rubtsov P, Karmanov M, Sverdlova P, Spirin P, Tiulpakov A. A novel homozygous mutation in CYP11A1 gene is associated with late-onset adrenal insufficiency and hypospadias in a 46, XY patient. $J$ Clin Endocrinol Metab. 2009;94(3):936-939. doi:10.1210/jc.2008-1118

49. Codner E, Okuma C, Iniguez G, et al. Molecular study of the 3 beta-hydroxysteroid dehydrogenase gene type II in patients with hypospadias. J Clin Endocrinol Metab. 2004;89(2):957-964. doi: $10.1210 /$ jc.2002-020873

50. Sata F, Kurahashi N, Ban S, et al. Genetic polymorphisms of $17 \beta-$ hydroxysteroid dehydrogenase 3 and the risk of hypospadias. J Sex Med. 2010;7(8):2729-2738.

51. Soderhall C, Korberg IB, Thai HT, et al. Fine mapping analysis confirms and strengthens linkage of four chromosomal regions in familial hypospadias. Eur J Hum Genet. 2015;23(4):516-522. doi:10.1038/ejhg.2014.129

52. Zimmermann S, Steding G, Emmen JM, et al. Targeted disruption of the Insl3 gene causes bilateral cryptorchidism. Mol Endocrinol. 1999;13(5):681-691. doi:10.1210/mend.13.5.0272

53. El Houate B, Rouba H, Sibai H, et al. Novel mutations involving the INSL3 gene associated with cryptorchidism. J Urol. 2007;177 (5):1947-1951. doi:10.1016/j.juro.2007.01.002 
54. Miyado M, Nakamura M, Miyado K, et al. Mamld1 deficiency significantly reduces mRNA expression levels of multiple genes expressed in mouse fetal Leydig cells but permits normal genital and reproductive development. Endocrinology. 2012;153 (12):6033-6040. doi:10.1210/en.2012-1324

55. Kalfa N, Liu B, Ophir K, et al. Mutations of CXorf6 are associated with a range of severities of hypospadias. Eur $J$ Endocrinol. 2008;159(4):453-458. doi:10.1530/EJE-08-0085

56. Fukami M, Wada Y, Miyabayashi K, et al. CXorf6 is a causative gene for hypospadias. Nat Genet. 2006;38(12):1369-1371.

57. Ratan SK, Sharma A, Kapoor S, et al. Polymorphism of 3' UTR of MAMLD1 gene is also associated with increased risk of isolated hypospadias in Indian children: a preliminary report. Pediatr Surg Int. 2016;32(5):515-524.

58. Luo X, Ikeda Y, Parker KL. A cell-specific nuclear receptor is essential for adrenal and gonadal development and sexual differentiation. Cell. 1994;77(4):481-490.

59. Gubbay J, Collignon J, Koopman P, et al. A gene mapping to the sex-determining region of the mouse $\mathrm{Y}$ chromosome is a member of a novel family of embryonically expressed genes. Nature. 1990;346(6281):245-250.

60. Kreidberg JA, Sariola H, Loring JM, et al. WT-1 is required for early kidney development. Cell. 1993;74(4):679-691. doi:10.1016/0092-8674(93)90515-R

61. Gao F, Maiti S, Alam N, et al. The Wilms tumor gene, Wt1, is required for Sox9 expression and maintenance of tubular architecture in the developing testis. Proc Natl Acad Sci USA. 2006;103(32):11987-11992.

62. Jameson JL, Achermann JC, Ozisik G, Meeks JJ. Battle of the sexes: new insights into genetic pathways of gonadal development. Trans Am Clin Climatol Assoc. 2003;114:51-63.

63. Peycelon M, Mansour-Hendili L, Hyon C, et al. Recurrent intragenic duplication within the NR5A1 gene and severe proximal hypospadias. Sex Dev. 2017;11(5-6):293-297. doi:10.1159/000485909

64. Wu JY, McGown IN, Lin L, et al. A novel NR5A1 variant in an infant with elevated testosterone from an Australasian cohort of 46,XY patients with disorders of sex development. Clin Endocrinol (Oxf). 2013;78(4):545-550.

65. Koehler B, Lin L, Mazen I, et al. The spectrum of phenotypes associated with mutations in steroidogenic factor 1 (SF-1, NR5A1, Ad4BP) includes severe penoscrotal hypospadias in 46, $\mathrm{XY}$ males without adrenal insufficiency. Eur $J$ Endocrinol. 2009;161(2):237-242.

66. Tuhan H, Anik A, Catli G, et al. A novel mutation in steroidogenic factor (SF1/NR5A1) gene in a patient with $46 \mathrm{XY}$ DSD without adrenal insufficiency. Andrologia. 2017;49(1):e12589. doi:10.1111/and.12589

67. Isidor B, Capito C, Paris F, et al. Familial frameshift SRY mutation inherited from a mosaic father with testicular dysgenesis syndrome. J Clin Endocrinol Metab. 2009;94(9):3467-3471. doi:10.1210/jc.2009-0226

68. Yucel S, Liu W, Cordero D, Donjacour A, Cunha G, Baskin LS. Anatomical studies of the fibroblast growth factor-10 mutant, sonic hedge hog mutant and androgen receptor mutant mouse genital tubercle. Adv Exp Med Biol. 2004;545:123-148.

69. Gredler ML, Seifert AW, Cohn MJ. Tissue-specific roles of Fgfr2 in development of the external genitalia. Development. 2015;142 (12):2203-2212. doi:10.1242/dev.119891

70. Seifert AW, Bouldin CM, Choi KS, Harfe BD, Cohn MJ. Multiphasic and tissue-specific roles of sonic hedgehog in cloacal septation and external genitalia development. Development. 2009;136(23):3949-3957. doi:10.1242/dev.042291

71. Miyagawa S, Matsumaru D, Murashima A, et al. The role of sonic hedgehog-Gli2 pathway in the masculinization of external genitalia. Endocrinology. 2011;152(7):2894-2903. doi:10.1210/ en.2011-0263
72. Perriton CL, Powles N, Chiang C, Maconochie MK, Cohn MJ. Sonic hedgehog signaling from the urethral epithelium controls external genital development. Dev Biol. 2002;247(1):26-46. doi: $10.1006 /$ dbio. 2002.0668

73. Beleza-Meireles A, Lundberg F, Lagerstedt K, et al. FGFR2, FGF8, FGF10 and BMP7 as candidate genes for hypospadias. Eur J Hum Genet. 2007;15(4):405-410. doi:10.1038/sj. ejhg. 5201777

74. Carmichael SL, Ma C, Choudhry S, Lammer EJ, Witte JS, Shaw GM. Hypospadias and genes related to genital tubercle and early urethral development. J Urol. 2013;190(5):1884-1892. doi:10.1016/j.juro.2013.05.061

75. Seifert AW, Yamaguchi T, Cohn MJJD. Functional and phylogenetic analysis shows that Fgf8 is a marker of genital induction in mammals but is not required for external genital development. Development. 2009;136(15):2643-2651. doi:10.1242/dev.036830

76. Ching ST, Cunha GR, Baskin LS, Basson MA, Klein OD. Coordinated activity of Spry1 and Spry2 is required for normal development of the external genitalia. Dev Biol. 2014;386(1):1-11.

77. Kajioka D, Suzuki K, Nakada S, et al. Bmp4 is an essential growth factor for the initiation of genital tubercle (GT) outgrowth. Congenit Anom (Kyoto). 2019.

78. Wu X, Ferrara C, Shapiro E, Grishina I. Bmp7 expression and null phenotype in the urogenital system suggest a role in re-organization of the urethral epithelium. Gene Expr Patterns. 2009;9(4):224-230. doi:10.1016/j.gep.2008.12.005

79. Lin C, Yin Y, Long F, Ma L. Tissue-specific requirements of beta-catenin in external genitalia development. Development. 2008;135(16):2815-2825. doi:10.1242/dev.020586

80. Chen T, Li Q, Xu J, et al. Mutation screening of BMP4, BMP7, HOXA4 and HOXB6 genes in Chinese patients with hypospadias. Eur J Hum Genet. 2007;15(1):23-28.

81. Fukuzawa R, Heathcott RW, Sano M, Morison IM, Yun K, Reeve AE. Myogenesis in Wilms' tumors is associated with mutations of the WT1 gene and activation of Bcl-2 and the wnt signaling pathway. Pediatr Dev Pathol. 2004;7(2):125-137. doi:10.1007/s10024-003-3023-8

82. Han X-R, Wen X, Wang S, et al. Associations of TGFBR1 and TGFBR2 gene polymorphisms with the risk of hypospadias: a case-control study in a Chinese population. Biosci Rep. 2017;37.

83. Placencio VR, Sharif-Afshar AR, Li X, et al. Stromal transforming growth factor-beta signaling mediates prostatic response to androgen ablation by paracrine Wnt activity. Cancer Res. 2008;68 (12):4709-4718. doi:10.1158/0008-5472.CAN-07-6289

84. Dravis C, Yokoyama N, Chumley MJ, et al. Bidirectional signaling mediated by ephrin-B2 and EphB2 controls urorectal development. Dev Biol. 2004;271(2):272-290. doi:10.1016/j. ydbio.2004.03.027

85. Mallo M, Wellik DM, Deschamps J. Hox genes and regional patterning of the vertebrate body plan. Dev Biol. 2010;344 (1):7-15. doi:10.1016/j.ydbio.2010.04.024

86. Morgan EA, Nguyen SB, Scott V, Stadler HS. Loss of Bmp7 and Fgf8 signaling in Hoxa13-mutant mice causes hypospadia. Development. 2003;130(14):3095-3109.

87. Podlasek CA, Duboule D, Bushman W. Male accessory sex organ morphogenesis is altered by loss of function of Hoxd-13. Dev Dyn. 1997;208(4):454-465.

88. Tuezel E, Samll H, Kuru I, et al. Association of hypospadias with hypoplastic synpolydactyly and role of HOXD13 gene mutations. Urology. 2007;70(1):161-164. doi:10.1016/j.urology.2007.03.013

89. Mortlock DP, Innis JW. Mutation of HOXA13 in hand-footgenital syndrome. Nat Genet. 1997;15(2):179-180.

90. Innis JW, Mortlock D, Chen Z, et al. Polyalanine expansion in HOXA13: three new affected families and the molecular consequences in a mouse model. Hum Mol Genet. 2004;13 (22):2841-2851. 
91. Behringer RR, Crotty DA, Tennyson VM, Brinster RL, Palmiter RD, Wolgemuth DJ. Sequences $5^{\prime}$ of the homeobox of the Hox-1.4 gene direct tissue-specific expression of lacZ during mouse development. Development. 1993;117(3):823-833.

92. Xu B, Geerts D, Bu Z, et al. Regulation of endometrial receptivity by the highly expressed HOXA9, HOXA11 and HOXD10 HOX-class homeobox genes. Hum Reprod. 2014;29(4):781-790.

93. Rancourt DE, Tsuzuki T, Capecchi MR. Genetic interaction between hoxb-5 and hoxb-6 is revealed by nonallelic noncomplementation. Genes Dev. 1995;9(1):108-122. doi:10.1101/gad.9.1.108

94. Horan GS, Wu K, Wolgemuth DJ, Behringer RR. Homeotic transformation of cervical vertebrae in Hoxa-4 mutant mice. Proc Natl Acad Sci U S A. 1994;91(26):12644-12648. doi:10.1073/pnas.91.26.12644

95. Geller F, Feenstra B, Carstensen L, et al. Genome-wide association analyses identify variants in developmental genes associated with hypospadias. Nat Genet. 2014;46(9):957-963. doi:10.1038/ ng.3063

96. Taylor HS, Fei X. Emx2 regulates mammalian reproduction by altering endometrial cell proliferation. Mol Endocrinol. 2005;19 (11):2839-2846. doi:10.1210/me.2005-0130

97. Miyamoto N, Yoshida M, Kuratani S, Matsuo I, Aizawa S. Defects of urogenital development in mice lacking Emx2. Development. 1997;124(9):1653-1664.

98. Piard J, Mignot B, Arbez-Gindre F, et al. Severe sex differentiation disorder in a boy with a $3.8 \mathrm{Mb} 10 \mathrm{q} 25.3-\mathrm{q} 26.12$ microdeletion encompassing EMX2. Am J Med Genet A. 2014;164A (10):2618-2622. doi:10.1002/ajmg.a.36662

99. Liu B, Agras K, Willingham E, Vilela ML, Baskin LS. Activating transcription factor 3 is estrogen-responsive in utero and upregulated during sexual differentiation. Horm Res. 2006;65(5):217-222.

100. Hartman MG, Lu D, Kim ML, et al. Role for activating transcription factor 3 in stress-induced beta-cell apoptosis. Mol Cell Biol. 2004;24(13):5721-5732. doi:10.1128/MCB.24.13.5721-5732.2 004

101. Beleza-Meireles A, Tohonen V, Soderhall C, et al. Activating transcription factor 3: a hormone responsive gene in the etiology of hypospadias. Eur $J$ Endocrinol. 2008;158(5):729-739. doi:10.1530/EJE-07-0793

102. Bhoj EJ, Ramos P, Baker LA, et al. Human balanced translocation and mouse gene inactivation implicate basonuclin 2 in distal urethral development. Eur J Hum Genet. 2011;19(5):540-546. doi:10.1038/ejhg.2010.245

103. Harms FL, Nampoothiri S, Anazi S, et al. Elsahy-waters syndrome is caused by biallelic mutations in CDH11. Am J Med Genet A. 2018;176(2):477-482. doi:10.1002/ajmg.a.38568

104. Hozyasz KK, Mostowska A, Kowal A, Mydlak D, Tsibulski A, Jagodzinski PP. Further evidence of the association of the diacylglycerol kinase kappa (DGKK) gene with hypospadias. Urol J. 2018;15(5):272-276.

105. van der Zanden LF, van Rooij IA, Feitz WF, et al. Common variants in DGKK are strongly associated with risk of hypospadias. Nat Genet. 2011;43(1):48-50. doi:10.1038/ng.721

106. Kojima Y, Koguchi T, Mizuno K, et al. Single nucleotide polymorphisms of HAAO and IRX 6 genes as risk factors for hypospadias. $J$ Urol. 2018.

107. Okur V, LeDuc CA, Guzman E, Valivullah ZM, Anyane-Yeboa $\mathrm{K}$, Chung WK. Homozygous noncanonical splice variant in LSM1 in two siblings with multiple congenital anomalies and global developmental delay. Cold Spring Harb Mol Case Stud. 2019;5(3):a004101. doi:10.1101/mcs.a004101

108. Zhang X, Chen Y, Zhao S, Markljung E, Nordenskjold A. Hypospadias associated with hypertelorism, the mildest phenotype of opitz syndrome. J Hum Genet. 2011;56(5):348-351. doi:10.1038/jhg.2011.17
109. Dokter EM, van Rooij IA, Wijers $\mathrm{CH}$, et al. Interaction between MTHFR $677 \mathrm{C}>\mathrm{T}$ and periconceptional folic acid supplementation in the risk of hypospadias. Birth Defects Res a Clin Mol Teratol. 2016;106(4):275-284. doi:10.1002/bdra.23487

110. Pinz H, Pyle LC, Li D, et al. De novo variants in Myelin regulatory factor (MYRF) as candidates of a new syndrome of cardiac and urogenital anomalies. Am J Med Genet A. 2018;176 (4):969-972. doi:10.1002/ajmg.a.38620

111. Riley DE, Cho IR, Krieger JN. A hemizygous short tandem repeat polymorphism $3^{\prime}$ to the human phosphoglycerate kinase gene. Mol Biol Rep. 1999;26(3):159-165. doi:10.1023/A:1006908624757

112. Amiel J, Espinosa-Parrilla Y, Steffann J, et al. Large-scale deletions and SMADIP1 truncating mutations in syndromic hirschsprung disease with involvement of midline structures. Am J Hum Genet. 2001;69(6):1370-1377. doi:10.1086/324342

113. Lancioni A, Pizzo M, Fontanella B, et al. Lack of Mid1, the mouse ortholog of the Opitz syndrome gene, causes abnormal development of the anterior cerebellar vermis. $J$ Neurosci. 2010;30(8):2880-2887. doi:10.1523/JNEUROSCI.4196-09.2010

114. Alimperti S, You H, George T, Agarwal SK, Andreadis ST. Cadherin-11 regulates both mesenchymal stem cell differentiation into smooth muscle cells and the development of contractile function in vivo. $J$ Cell Sci. 2014;127(Pt 12):2627-2638. doi: $10.1242 /$ jcs. 134833

115. Shi H, Enriquez A, Rapadas M, et al. NAD deficiency, congenital malformations, and niacin supplementation. $N$ Engl J Med. 2017;377(6):544-552. doi:10.1056/NEJMoa1616361

116. Danshina PV, Geyer CB, Dai Q, et al. Phosphoglycerate kinase 2 (PGK2) is essential for sperm function and male fertility in mice. Biol Reprod. 2010;82(1):136-145. doi:10.1095/biolreprod.109.079699

117. Lin C, Werner R, Ma L, Miner JH. Requirement for basement membrane laminin alpha5 during urethral and external genital development. Mech Dev. 2016;141:62-69. doi:10.1016/j. mod.2016.05.004

118. Cunha GR, Sinclair A, Risbridger G, Hutson J, Baskin LS. Current understanding of hypospadias: relevance of animal models. Nat Rev Urol. 2015;12(5):271-280. doi:10.1038/ nrurol.2015.57

119. Gray LE, Ostby J, Furr J, et al. Effects of environmental antiandrogens on reproductive development in experimental animals. Hum Reprod Update. 2001;7(3):248-264. doi:10.1093/humupd/7.3.248

120. Rider CV, Furr JR, Wilson VS, Gray LE Jr. Cumulative effects of in utero administration of mixtures of reproductive toxicants that disrupt common target tissues via diverse mechanisms of toxicity. Int $J$ Androl. 2010;33(2):443-462. doi:10.1111/j.1365-2605.2009. 01049.x

121. Tan XH, Liu X, Long CL, et al. Histological and biochemical evaluation of urethral scar following three different hypospadias repairs: an experimental study in rabbits. Eur J Pediatr Surg. 2018;28(5):420-425. doi:10.1055/s-0037-1605347

122. Switonski M, Dzimira S, Aleksiewicz R, et al. Hypospadias is not rare in dogs: five new cases, a retrospective study, and a review of the literature. Sex Dev. 2018. doi:10.1159/000490079

123. Nowacka-Woszuk J, Szczerbal I, Salamon S, et al. Testicular disorder of sex development in four cats with a male karyotype (38,XY; SRY-positive). Anim Reprod Sci. 2014;151(1-2):42-48. doi:10.1016/j.anireprosci.2014.10.001

124. Smith KC, Brown PJ, Barr FJ. A survey of congenital reproductive abnormalities in rams in abattoirs in south west England. Reprod Domest Anim. 2012;47(5):740-745. doi:10.1111/j.14390531.2011.01952.x

125. Iannuzzi A, Braun M, Genualdo V, et al. Clinical, cytogenetic and molecular genetic characterization of a tandem fusion translocation in a male Holstein cattle with congenital hypospadias and a ventricular septal defect. PLoS One. 2020;15(1):e0227117. doi:10.1371/journal.pone. 0227117 
126. De Lorenzi L, Genualdo V, Iannuzzi A, et al. Cytogenetic and genetic studies in a hypospadic horse (Equus caballus, $2 \mathrm{n}=64$ ). Sex Dev. 2010;4(6):352-357. doi:10.1159/000319527

127. Krzeminska P, D'Anza E, Ciotola F, et al. Polymorphisms of MAMLD1, SRD5A2, and AR candidate genes in seven dogs (78,XY; SRY-Positive) affected by hypospadias or cryptorchidism. Sex Dev. 2019;13(2):92-98. doi:10.1159/ 000500219

128. Cassata R, Iannuzzi A, Parma P, et al. Clinical, cytogenetic and molecular evaluation in a dog with bilateral cryptorchidism and hypospadias. Cytogenet Genome Res. 2008;120(1-2):140-143. doi:10.1159/000118753

129. Szczerbal I, Nowacka-Woszuk J, Nizanski W, et al. Disorders of sex development are an emerging problem in French bulldogs: a description of six new cases and a review of the literature. Sex Dev. 2019;13(4):205-211. doi:10.1159/000506582

130. Mihsler L, Hussein HA, Wehrend A. Perineal hypospadia in a red holstein-calf. A case report. Tierarztl Prax Ausg G Grosstiere Nutztiere. 2015;43(2):105-108.

131. Galanty M, Jurka P, Zielinska P. Surgical treatment of hypospadias. Techniques and results in six dogs. Pol J Vet Sci. 2008;11 (3):235-243.

132. Li Y, Sinclair A, Cao M, et al. Canalization of the urethral plate precedes fusion of the urethral folds during male penile urethral development: the double zipper hypothesis. J Urol. 2015;193 (4):1353-1359. doi:10.1016/j.juro.2014.09.108

133. Overland M, Li Y, Cao M, et al. Canalization of the vestibular plate in the absence of urethral fusion characterizes development of the human clitoris: the single zipper hypothesis. J Urol. 2016;195(4 Pt 2):1275-1283. doi:10.1016/j.juro.2015.07.117

134. Seifert AW, Harfe BD, Cohn MJ. Cell lineage analysis demonstrates an endodermal origin of the distal urethra and perineum. Dev Biol. 2008;318(1):143-152. doi:10.1016/j.ydbio.2008.03.017
135. Liu G, Liu X, Shen J, Sinclair A, Baskin L, Cunha GR. Contrasting mechanisms of penile urethral formation in mouse and human. Differentiation. 2018;101:46-64. doi:10.1016/j. diff.2018.05.001

136. Sinclair AW, Cao M, Shen J, et al. Mouse hypospadias: a critical examination and definition. Differentiation. 2016;92(5):306-317. doi:10.1016/j.diff.2016.03.004

137. Kluth D, Fiegel HC, Geyer C, Metzger R. Embryology of the distal urethra and external genitals. Semin Pediatr Surg. 2011;20 (3):176-187. doi:10.1053/j.sempedsurg.2011.03.003

138. Rodriguez E Jr, Weiss DA, Ferretti M, et al. Specific morphogenetic events in mouse external genitalia sex differentiation are responsive/dependent upon androgens and/or estrogens. Differentiation. 2012;84(3):269-279. doi:10.1016/j.diff.2012.07. 003

139. Goldfoot DA, Resko JA, Goy RW. Induction of target organ insensitivity to testosterone in male guinea-pig with cyproterone. J Endocrinol. 1971;50(3):423-429. doi:10.1677/ joe.0.0500423

140. Connolly PB, Resko JA. Role of steroid 5-alpha-reductase activity in sexual-differentiation of the guinea-pig. Neuroendocrinology. 1989;49(3):324-330. doi:10.1159/ 000125134

141. Price D, Ortiz E, Zaaijer JJJTAR. Organ culture studies of hormone secretion in endocrine glands of fetal guinea pigs III. The relation of testicular hormone to sex differentiation of the reproductive ducts. Anat Rec. 1967;157(1):27-41. doi:10.1002/ ar. 1091570106

142. Wang S, Zheng Z. Differential cell proliferation and cell death during the urethral groove formation in guinea pig model. Pediatr Res. 2019;86(4):452-459. doi:10.1038/s41390-018-0236-0

\section{Publish your work in this journal}

Research and Reports in Urology is an international, peer-reviewed, open access journal publishing original research, reports, editorials, reviews and commentaries on all aspects of adult and pediatric urology in the clinic and laboratory including the following topics: Pathology, pathophysiology of urological disease; Investigation and treatment of urological disease; Pharmacology of drugs used for the treatment of urological disease. The manuscript management system is completely online and includes a very quick and fair peer-review system, which is all easy to use. Visit http://www.dovepress.com/ testimonials.php to read real quotes from published authors 